\title{
COMFORT CHARACTERISTICS ADDED TO KNITTED FABRICS FROM FLAX \COTTON BLENDED SPUN YARNS USING COTTON RING SPINNING SYSTEM
}

\author{
SUZAN H. SANAD
}

\author{
Cotton Research Institute, Agricultural Research Center, Giza-Egypt
}

(Manuscript received 4 November 2010 )

\begin{abstract}
This investigation was carried out to estimate and compare comfort properties of blended yarns and knitted fabrics, made with different proportions of cottonised flax and long staple Egyptian cotton (Giza80) using ring spinning system. Cottonised flax was blended in proportions of $30 \%, 50 \%$ and $70 \%$ with Giza 80 on draw-frame process. The $100 \%$ cotton sample was also spun to identical count for comparison purpose. All the samples were spun to 20s, 30s, and 40s (cotton system) at a constant twist multiplier "4.0, using the ring spinning. Further, yarn samples were suitably waxed and identically knitted into single jersey fabrics with the same construction. Cotton and flax fibers, yarns and knitted fabrics quality properties were tested and evaluated according to ASTM.

The main findings could be summarized as follows:

1. The $100 \%$ cotton yarns were significantly of higher yarn strength, elongation and evenness "CVm\%" and of lower imperfections compared with the cotton/flax blended yarns.

2. A comparison of the bursting strength of the knitted fabric showed that those made from cotton blended with cottonised flax yarns generally have lower bursting strength than those made from $100 \%$ cotton yarn.

3. Color Efficiency $(K \backslash S)$ value of the flax-blended knitted fabrics were slightly higher than the cotton knitted fabrics, however the differences between different flax blend ratios were statistically insignificant.

4. Adding flax to cotton knitted fabrics increase the Ultraviolet Protection Factor (UPF) and it could be considered as an effective protection against ultraviolet rays. UPF increased in respective of the increased flax component and decreased yarn count.

5. The results showed that the knitted flax blended fabrics permit more moisture absorption, as compared to the $100 \%$ cotton knitted fabrics. This could be attributed to the large diameter of the flax fiber. The difference between cotton and its blends with flax was statistically significant.

The air permeability, moisture regain and UPF results revealed that the knitted fabrics made from cotton/cottonised flax are more suitable for summer dress material, because of its high air permeability when dry very rapidly and high UPF.
\end{abstract}

\section{INTRODUCTION}

Natural textile materials are in vogue nowadays. Flax is used by the textile industry as specialty fiber to create a distinctive fabric with unique characteristics. 
Natural fibers, such as flax, are sought in blends due to their strength, low abrasiveness, abundance, renewability, non-hazardous nature, biodegradability, low density, recyclability, low equipment requirements and cost. Collectively, composites are light, stiff, strong, and allow both large and small scale production at lower energy costs. The light weights of these composites also increase the energy efficiency for machinery and transportation, (Foulk et al. 2006).

Kandolph and Langford, (2002) stated that comfort in clothing is impacted by uncomfortable feelings of wetness when the body of the wearer begins to sweat in order to release body heat. Garments that absorb body fluid, which are mainly water and water vapor, can reduce the level of discomfort. Bliss and Foulk (2005) reported that Flax is two to three times stronger than cotton, making it one of the strongest natural fibers known. Adding flax to clothing fabrics helps keep skin cool partly because the flax improves moisture wicking, which means channeling moisture away from the skin's surface. Another important feature of moisture management is air permeability, which allows fabrics to dry quickly. If a fabric dries fast because it has high air permeability but it also has low moisture wicking capacity, the moisture won't be absorbed sufficiently to be pulled away from the skin. Wearing $100 \%$ cotton clothing during exercise can make skin feel clammy since it does not dry quickly. Adding flax to the blend allows for better moisture management with high air permeability, which allows fabric to dry more quickly. Foulk et. al. (2006) reported that Fibers from flax are stiff and strong and can be processed into a yarn and then manufactured into a fabric for composite formation. As increase the blend percentage and mass of flax fibers with cotton, increases the fabric strength and elongation generally.

Strumillo et al. (2004) found that the tenacity of blended yarns decreases with the increase of flax in the blend. The partial models described in the paper allow the prediction of yarn tenacity for different yarn linear densities and flax percentage contents. The number of faults, i.e. of thin \& thick places and of neps, is the lowest for pure cotton yarn. The number of faults increases non-linearly with the increase in flax content in the blend. The hairiness increases with the increase in the yarns' linear density.

Cierpucha et al. (2006) studied quality properties of cotton yarns and its blends with flax. Compared to all-cotton yarns, the blended yarns with flax are characterized by lower strength (about 10\% lower) and higher coefficients of variation of linear density and strength. The differences between the two types of yarn are due, inter alia to the fact that cotton is much thinner than cottonised flax, which makes a significant difference as far as the number of fibers in the yarn cross-section is 
concerned. In addition to that, cotton, owing to its shape, has a greater suitability for spinning than cottonised flax. To ensure a smooth process when spinning a flax/cotton blend, it is necessary to use a higher twist factor, of the order of $10-12 \%$.

Behera (2007) showed that the addition of either cotton or viscose to flax helps to reduce its bending rigidity, lower surface friction and surface roughness and further improves the hand value of flax-blended fabrics. $100 \%$ flax fabrics give the lowest shear rigidity and shear hysteresis, as compared to $100 \%$ cotton and flax/cotton and flax/viscose blends fabrics. Finished cotton fabrics have the highest total appearance value, followed by flax and flax-blended fabrics. $100 \%$-flax and flaxblended fabrics have higher thermal insulation values and more permeable to air than cotton fabrics, which confirms the suitability of flax fabric for summer wear. Flax fabric has a higher moisture vapor transmission rate compared to cotton fabric, due to its higher affinity to moisture and its better air permeability.

The aim of this investigation was to estimate and compare comfort properties of blended yarns and knitted fabrics, made with different proportions of flax and long staple Egyptian cotton (G80) using ring spinning system.

\section{MATERIALS AND METHODS}

The flax fibers were cut into Short Staple length on a staple cutter machine to produce cottonised flax. The cottonised flax fiber samples were evaluated for fiber length $(28 \mathrm{~mm})$, fiber fineness (300 mtex) and fiber strength $(50 \mathrm{~g} / \mathrm{tex})$ in the laboratories of Al-Sharkia for Flax and Cotton Company. Cottonised flax was blended with long staple Egyptian cotton Giza 80, measured by HVI spectrum instrument having Upper Half Mean length of $31.3 \mathrm{~mm}$, uniformity ratio of $85 \%$, micronaire value of 4.2 , fineness of 169 mtex, strength of $37.0 \mathrm{~g} /$ tex, elongation $(7.5 \%)$ maturity ratio of (0.93). Blending flax was in proportions of $30 \%, 50 \%$ and $70 \%$ with $\mathrm{G} 80$ on drawframe process. The cotton sample was also spun to identical count for comparison purpose. All the blends were spun to $20 \mathrm{~s}, 30 \mathrm{~s}$, and $40 \mathrm{~s}$ "cotton system" at a constant twist multiplier "4.0, using the ring spinning procedure as mentioned in Table 1. Table 1. Outline of spinning procedure

\begin{tabular}{|c|c|c|c|c|}
\hline \multirow{2}{*}{ Properties } & \multicolumn{4}{|c|}{ Cotton\flax blend } \\
\hline & $100 \%$ Cotton & $70 \% \mathrm{Cl} 30 \% \mathrm{~F}$ & $50 \% \mathrm{C} \backslash 50 \% \mathrm{~F}$ & $30 \% \mathrm{C} \backslash 70 \% \mathrm{~F}$ \\
\hline Roving count & \multicolumn{4}{|c|}{0.90 hank } \\
\hline Roving machine & \multicolumn{4}{|c|}{ BCX 16-A Marzoli } \\
\hline Roving Speed (rpm) & \multicolumn{4}{|c|}{$600 \mathrm{rpm}$} \\
\hline Spinning Machine & \multicolumn{4}{|c|}{ RST 1 Marzoli } \\
\hline Spindle Speed (rpm) & \multicolumn{4}{|c|}{15000} \\
\hline Yarn Count (Ne) & 20 & & 30 & 40 \\
\hline Twist Multiplier & \multicolumn{4}{|c|}{4.0} \\
\hline Ring diameter & \multicolumn{4}{|c|}{$45 \mathrm{~mm}$} \\
\hline
\end{tabular}


Yarn tenacity (cN/Tex) and elongation at break (\%) were measured on a Statimat ME with 120 breaks per sample. Yarn evenness (CVm \%) and imperfections values were measured on Uster Tester 3 (the measurement length was 400 $\mathrm{m} /$ bobbin). The obtained data were subjected to statistical analysis in completely randomized factorial design with six replications according to Draper and Smith 1966.

Further, yarn samples were suitably waxed and identically knitted into single jersey fabric with the same construction on a $8.89 \mathrm{~cm}$ (3.5 inch) diameter, Goge 12 with 12 needles per $\mathrm{cm}$ by DM commercial knitting machine. This was followed by Cairo Secondary School for spinning and weaving.

The knitted fabrics were evaluated for bursting strength with a diaphragm type bursting tester according to the standard method. Air permeability was determined by Prolific Air Permeability tester according to the standard procedure (ASTM D 737-04) and the results were expressed in terms of $\mathrm{m} 3 / \mathrm{m} 2 / \mathrm{min}$.

The color yield of the dyed samples was evaluated by reflectance technique using data color SF-600 spectrophotometer. The color strength expressed as K/S values of the dyed samples were obtained from the measuring software by applying the equation as follows:

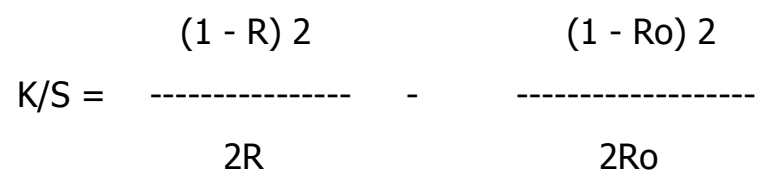

Where:-

R: Decimal fraction of the reflectance of dyed samples

Ro: Decimal fraction of the reflectance of undyed samples.

K: Absorption coefficient.

S: scattering coefficient

Measurements of moisture regain of the samples were performed according to the standard ASTM (D. 2495-87). Moisture regain of the samples was then determined according to the following equation:

$\begin{array}{lc}\text { Moisture regain } \%= & \text { W I-W2 } \\ \text { Where, } & \text { W2 }\end{array}$

W1: Weight of the sample (g.) after saturation in standard humidity atmosphere.

W2: $\quad$ Constant weight of dry sample (g.). 
Ultraviolet protection factor (UPF) is the scientific term used to indicate the amount of Ultraviolet (UV) protection provided to skin by fabric (ASTM-D 6603-00). The UPF is calculated as follows:

$$
U P F=\frac{E D}{E D_{m}}=\frac{\sum_{290 \mathrm{~mm}}^{400 \mathrm{~mm}} E_{\lambda} S_{\lambda} \Delta \lambda}{\sum_{200 \mathrm{~mm}}^{40 \mathrm{~mm}} E_{\lambda} S_{\lambda} T_{\lambda} \Delta \lambda}
$$

where:

$\mathrm{E} \lambda=$ relative erythemal spectral effectiveness

S $\lambda=$ solar spectral irradiance

$\mathrm{T} \lambda=$ average spectral transmittance of the sample (measured)

$\Delta \lambda=$ measured wavelength interval $(\mathrm{nm})$

Fabric testing was carried out at Textile Research Division, National Institute for Standards.

\section{RESULTS AND DISCUSSION}

\section{Yarn properties}

Under comparable conditions cotton, was ring-spun into $100 \%$ cotton yarn numbers of 20,30 , and $40, \mathrm{Ne}$. The quality indices of these yarns were presented in Tables 2 and 3.

On the basis of the data presented in Tables 2 and 3, the results illustrate the differences between the values of the quality parameters of the ring-spun cotton yarns and those of the yarns made from cotton-blended with cottonised flax in a large proportion.

As shown in figures 1 and 2, the general trends revealed that the yarn strength decreased significantly with increasing yarn count. In the ring spinning, the strongest yarns were produced from $100 \%$ cotton, and then, the strength decreased with increasing the flax fibers percentage in the blend. A comparison of the single yarn strength of the yarns shows that those made from cotton blended with cottonised flax generally have lower yarn strength than those made from $100 \%$ cotton by about $22.2 \%, 13.3 \%$ and $6.8 \%$ for $70 \%$ flax $/ 30 \%$ cotton, $50 \%$ flax $/ 50 \%$ cotton, and $30 \%$ flax $/ 70 \%$ cotton respectively.

The yarn elongation was higher in the case of the $100 \%$ cotton yarns, than the blended cotton/flax yarn, Figure 3.

Tables 2 and 3 and figures 1 and 4 illustrated that the 100\% cotton yarn was of significantly higher yarn evenness "CVm\%" and lower imperfections compared with 
the cotton/flax blended yarns. It could be shown that the yarn evenness and imperfections deteriorated steadily as the yarn becomes finer as well as the flax percentage increases in the blends.

Yarns spun of $100 \%$ cotton showed better results than corresponding cotton (flax yarns, this is referred to the fineness of cotton fibers. There are many more individual fibers in the cross-section of a $100 \%$ cotton yarn, due to its fineness "154 mtex" than in the corresponding cross-section of flax/cotton yarn. The number of fibers in the cross-section of a yarn has a determinant effect on its quality. In addition to that, the inferior quality parameters of the blended yarn are due to the difference in the physical structure and shape between cotton and cottonised flax, to the advantage of cotton.

Table 2. Effect of blend ratio on yarn quality properties.

\begin{tabular}{|c|c|c|c|c|c|c|}
\hline \multirow{2}{*}{$\begin{array}{c}\text { Yarn } \\
\text { construction }\end{array}$} & $\begin{array}{c}\text { Ytrength } \\
\mathrm{cN} / \mathrm{tex}\end{array}$ & Elongation\% & $\mathrm{CVm} \%$ & $\begin{array}{c}\text { Thin } \\
\text { places }\end{array}$ & $\begin{array}{c}\text { Thick } \\
\text { places }\end{array}$ & $\begin{array}{c}\text { Nep } \\
\text { count }\end{array}$ \\
\cline { 2 - 7 } & 14.72 & 4.98 & 25.03 & 226 & 268 & 270 \\
\hline $70 \% \mathrm{f} / 30 \% \mathrm{c}$ & 16.38 & 5.22 & 23.60 & 205 & 264 & 247 \\
\hline $50 \% \mathrm{f} / 50 \% \mathrm{c}$ & 17.63 & 5.67 & 19.83 & 199 & 247 & 228 \\
\hline $30 \% \mathrm{f} / 70 \% \mathrm{c}$ & 18.93 & 6.06 & 16.80 & 168 & 190 & 188 \\
\hline $100 \% \mathrm{cotton}$ & $\mathbf{1 . 0 5}$ & $\mathbf{0 . 8 1}$ & $\mathbf{1 . 1 7}$ & $\mathbf{7 . 7 1}$ & $\mathbf{8 . 7 6}$ & $\mathbf{9 . 0 2}$ \\
\hline LSD at 5\% & & & & & \\
\hline
\end{tabular}

Table 3. Effect of yarn count and blend ratio on yarn quality properties.

\begin{tabular}{|c|c|c|c|c|c|c|c|}
\hline \multirow{2}{*}{$\begin{array}{l}\text { Yarn } \\
\text { count }\end{array}$} & \multirow{2}{*}{$\begin{array}{c}\text { Yarn } \\
\text { construction }\end{array}$} & \multicolumn{6}{|c|}{ Yarn properties } \\
\hline & & $\begin{array}{c}\text { Strength } \\
\text { cN/tex }\end{array}$ & Elongation \% & $\mathrm{CVm} \%$ & $\begin{array}{l}\text { Thin } \\
\text { places }\end{array}$ & $\begin{array}{l}\text { Thick } \\
\text { places }\end{array}$ & $\begin{array}{l}\text { Nep } \\
\text { count }\end{array}$ \\
\hline \multirow{4}{*}{$20 \mathrm{~s}$} & $70 \% f / 30 \% c$ & 15.49 & 5.37 & 23.62 & 167 & 246 & 247 \\
\hline & $50 \% \mathrm{f} / 50 \% \mathrm{c}$ & 17.17 & 5.51 & 22.72 & 156 & 227 & 208 \\
\hline & $30 \% \mathrm{f} / 70 \% \mathrm{c}$ & 19.02 & 6.00 & 17.75 & 156 & 201 & 196 \\
\hline & $100 \%$ cotton & 20.24 & 6.40 & 16.16 & 133 & 113 & 114 \\
\hline \multirow{4}{*}{$30 \mathrm{~s}$} & $70 \% f / 30 \% c$ & 14.87 & 5.03 & 25.25 & 235 & 258 & 272 \\
\hline & $50 \% \mathrm{f} / 50 \% \mathrm{c}$ & 16.67 & 5.07 & 23.29 & 202 & 227 & 258 \\
\hline & $30 \% \mathrm{f} / 70 \% \mathrm{c}$ & 17.49 & 5.57 & 20.36 & 196 & 264 & 224 \\
\hline & $100 \%$ cotton & 19.11 & 6.07 & 16.95 & 176 & 211 & 208 \\
\hline \multirow{4}{*}{$40 \mathrm{~s}$} & $70 \% f / 30 \% c$ & 13.81 & 4.53 & 26.22 & 275 & 301 & 290 \\
\hline & $50 \% \mathrm{f} / 50 \% \mathrm{c}$ & 15.29 & 5.10 & 24,80 & 258 & 290 & 276 \\
\hline & $30 \% \mathrm{f} / 70 \% \mathrm{c}$ & 16.37 & 5.43 & 21.37 & 247 & 275 & 265 \\
\hline & $100 \%$ cotton & 17.45 & 5.70 & 17.29 & 195 & 246 & 243 \\
\hline \multicolumn{2}{|c|}{ LSD at $5 \%$} & 1.38 & 1.06 & 1.54 & 10.15 & 11.53 & 11.87 \\
\hline
\end{tabular}




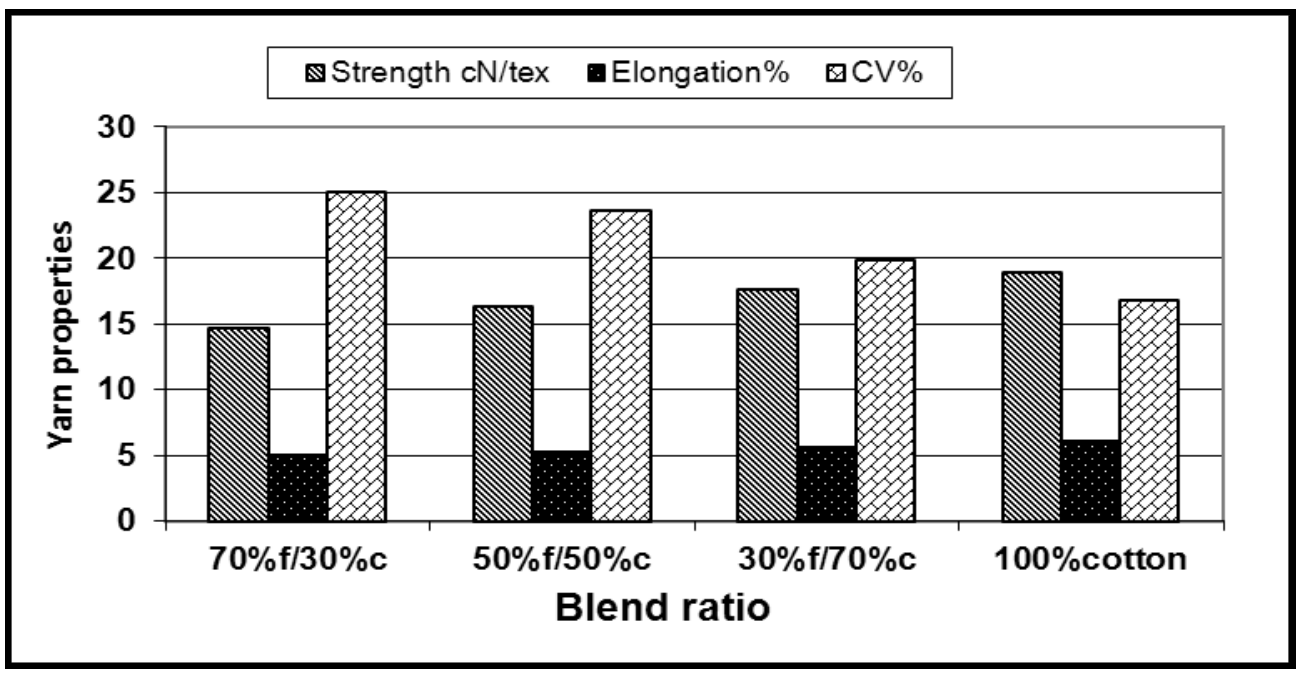

Figure 1. Effect of blend ratio on yarn quality properties

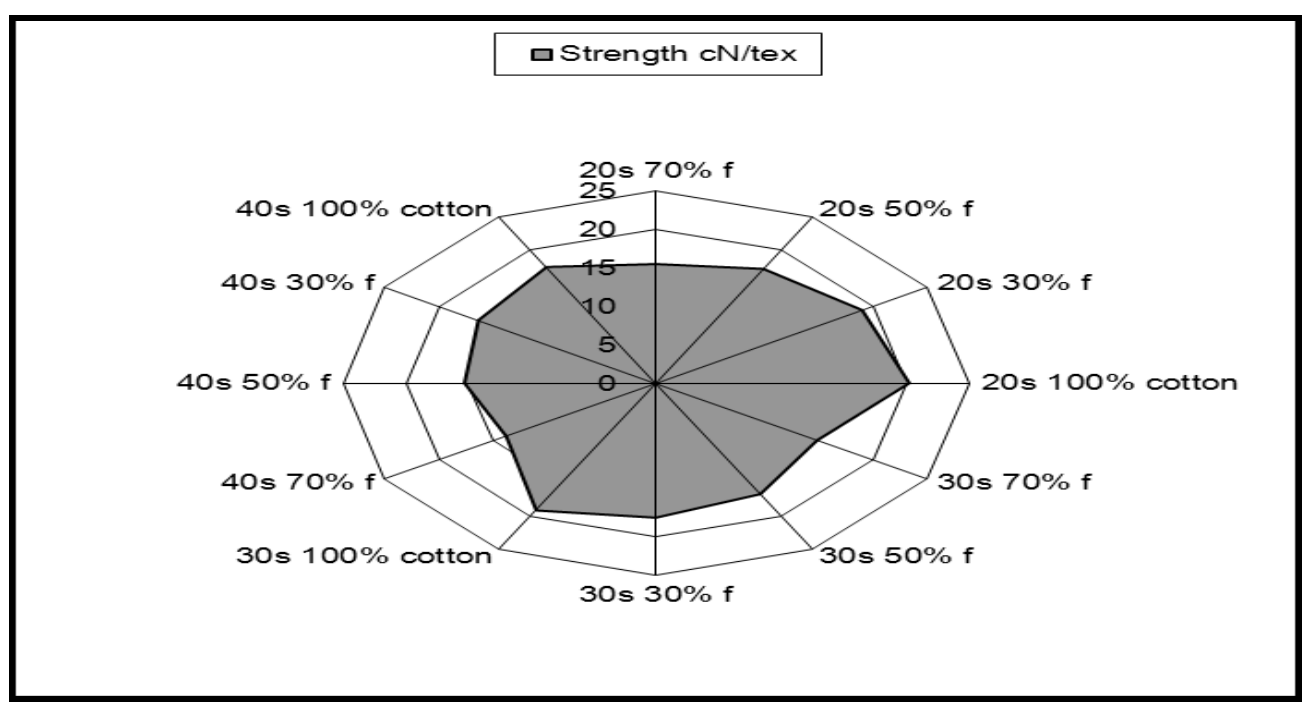

Figure 2. Effect of yarn count and blend ratio on single yarn strength

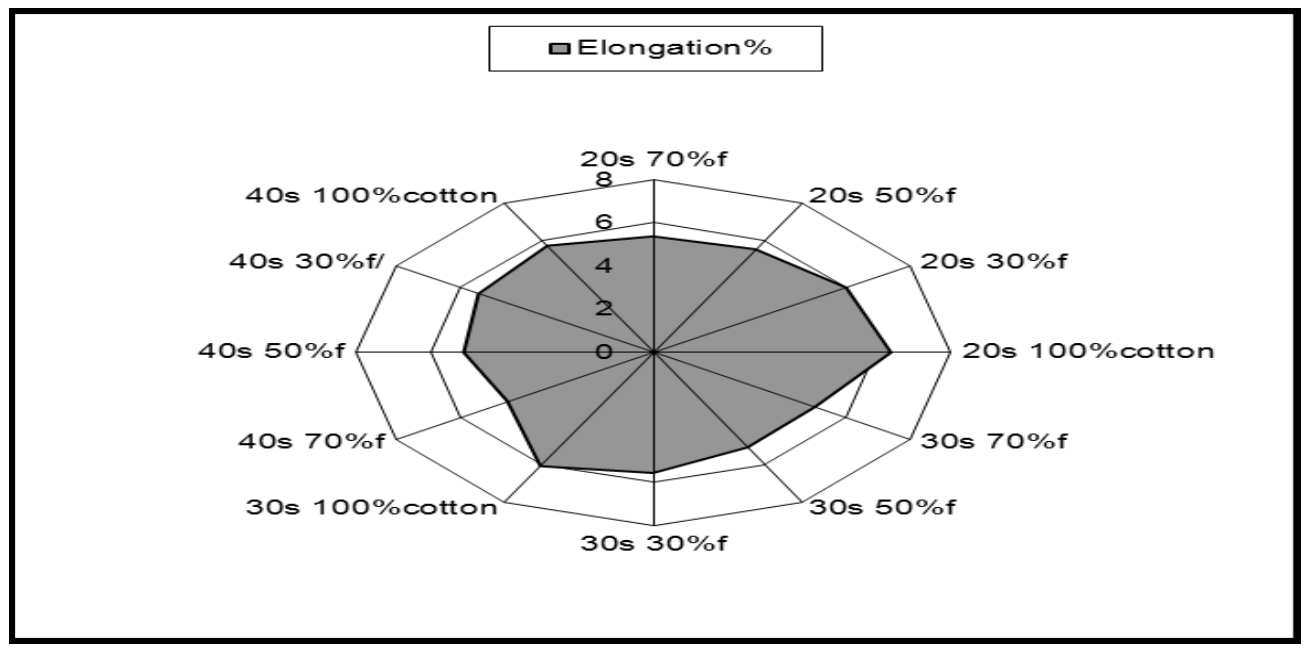

Figure 3. Effect of yarn count and blend ratio on yarn Elongation 


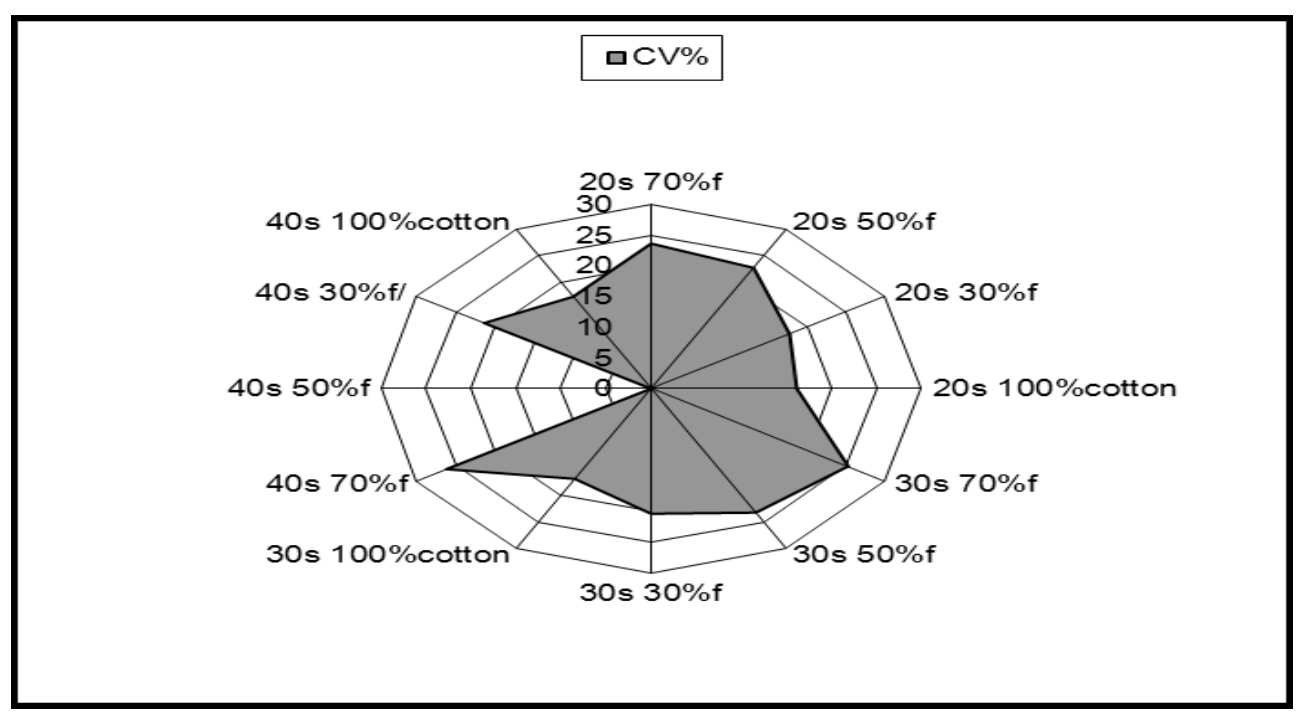

Figure 4. Effect of yarn count and blend ratio on yarn evenness CVm\%

\section{Knitted fabrics properties}

The desired attributes of knitting fabrics are to have durability characteristics, such as tearing and tensile strength and comfort characteristics i.e., wicking, vapor transmission, Ultraviolet Protection Factor (UPF) and air permeability. The results of knitted fabrics quality properties of cotton and flax/cotton blends, on the basis of the data, are presented in Tables 4, 5 and 6 .and illustrated in figures 5 and 6.

\section{- Bursting strength results $(\mathbf{k g} \backslash \mathrm{cm} 2)$}

Testing results from the bursting strength test, which determines the breaking strength of the knitted fabric, show that the strongest fabrics were those produced from $100 \%$ cotton yarn, and then, the bursting strength decreased with increasing the flax ratio in cotton/flax blended knitted fabrics. A comparison of the bursting strength of the fabric shows that those made from cotton blended with cottonised flax yarns generally have lower bursting strength than those made from $100 \%$ cotton yarn by about $47.04 \%$, $35.45 \%$ and $18.25 \%$ for $70 \%$ flax $/ 30 \%$ cotton, $50 \%$ flax $/ 50 \%$ cotton, and $30 \%$ flax $/ 70 \%$ cotton respectively. In addition, there were significant differences among the $100 \%$ cotton fabrics and its blends with flax. Also, fabrics made from different yarn counts (20s, 30s and 40s) had a significant effect on bursting strength. As yarn count increased, the bursting strength of the knitted fabrics decreased. These results could be emphasized by the same finding in single yarn strength.

\section{- Air permeability results $(\mathrm{m} 3 / \mathrm{m} 2 / \mathrm{min}$.)}

The results of air permeability, in terms of the amount of air passing through a unit fabric area per unit time, are given in Tables 4,5 and 6 and illustrated in figures 5 and 6 . The results show that flax blended fabrics permit more air to pass through, as compared to $100 \%$ cotton fabrics of similar areal density. The reason for the higher 
permeability in the case of flax-blended fabrics can be attributed to the large diameter of the flax fiber "fiber fineness of flax 300 mtex, as compared with 154 mtex of cotton fiber", which carried out the low packing density of the yarn. Flax fibers, being coarser as compared with cotton fibers, also assist the easy passage of air through the yarn cross-section, which results in higher air permeability. The results show that the blend ratio had a significant effect on the air permeability. It was found that the air permeability increases in respective of increased flax component. The effect of air permeability on comfort properties is much greater when the speed of air is high. In addition, fabrics made from different yarn counts (20s, 30s and 40s) had a significant effect on air permeability.

\section{- Color Efficiency (K\S)}

Color Efficiency $(K \backslash S)$ value of the flax-blended knitted fabrics were slightly higher than the cotton knitted fabrics, however the difference between different flax blend ratios was statistically insignificant. It was shown that color efficiency of the fabrics knitted with $20 \backslash 1 \mathrm{Ne}$ were slightly higher than the fabrics knitted with $30 \backslash 1 \mathrm{Ne}$ and fabrics knitted with $40 \backslash 1 \mathrm{Ne}$ successively, however these differences were statistically insignificant as shown in Tables 4 and 5 and figures 5 and 6.

\section{- Ultraviolet Protection Factor (UPF)}

As mentioned by Capjack et. al. (1994), high short-term exposure to Ultraviolet Radiation (UR) from the sun causes sunburns and long-term exposure leads to skin cancer. The National Toxicology Program, U.S. Department of Health and Human Services has classified UR as a known human carcinogen. The most frequently recommended form of UV protection is the use of sunscreens, hats, and proper selection of clothing.

Ultraviolet Protection Factor (UPF) is the scientific term used to indicate the amount of Ultraviolet protection provided to skin by fabric, which considered a comfort requirement. The (UPF) values of the flax-blended knitted fabrics were better than the cotton knitted fabrics. Blend ratio had a significant effect on UPF. As flax ratio increased, the UPF of the knitted fabrics increased, this can be explained by flax fiber properties. Fabrics made from different yarn counts (20s, 30s and 40s) had a significant effect on UPF. As yarn count increased, the UPF of the knitted fabrics decreased, which meant that the UPF of the knitted fabrics produced with $40 \backslash 1 \mathrm{Ne}$ yarns were lower than fabrics knitted with $30 \backslash 1$, yarns lower than fabrics knitted with20 1 yarns successively this can be explained by increase the yarn cross-section as mentioned in Tables 4 and 5 and figures 5 and 6 . 


\section{- Moisture regain}

An ideal fabric should allow water vapor on skin (perspiration) to pass through its pores, irrespective of the fiber material's natural absorbency. If the water vapor cannot escape at a faster rate than it was released by the skin, the wearer feels uncomfortable, Behera (2007). In order to assess the fabric's ability to permit moisture through it in a steady state, moisture regain is measured and the results were presented in Tables 4, 5 and 6 . The results show that flax blended fabrics permit more moisture absorbed through it, as compared to $100 \%$ cotton fabrics. This could be attributed to the large diameter of the flax fiber, i.e., fiber fineness. However the difference between different flax blend ratio (70\%f, 50\% and 30\%f) was statistically significant. It was shown that moisture absorbed by the fabrics knitted with $20 \backslash 1 \mathrm{Ne}$ was slightly higher than the fabrics knitted with $30 \backslash 1 \mathrm{Ne}$ and fabrics knitted with $40 \backslash 1 \mathrm{Ne}$ successively.

The air permeability, moisture regain and UPF results reveal that the fabrics made from cotton/cottonised flax are more suitable for summer dress material. $100 \%$ cotton fabrics don't dry very fast after sponging water up, while adding flax provides enough air permeability to speed up drying and high UPF

Table 4. Effect of blend ratio on knitted fabrics quality properties

\begin{tabular}{|c|c|c|c|c|c|}
\hline \multirow{2}{*}{$\begin{array}{c}\text { Fabric } \\
\text { Construction }\end{array}$} & \multicolumn{5}{|c|}{ Knitted Fabrics properties } \\
\cline { 2 - 6 } & $\begin{array}{c}\text { Bursting strength } \\
\mathrm{kg} / \mathrm{cm} 2\end{array}$ & $\begin{array}{c}\text { Air permeability } \\
\mathrm{m} 3 / \mathrm{m} 2 / \mathrm{min} .\end{array}$ & $\mathrm{K} / \mathrm{S}$ & UPF & $\begin{array}{c}\text { Moisture } \\
\text { regain\% }\end{array}$ \\
\hline $70 \% \mathrm{f} / 30 \% \mathrm{c}$ & 10.47 & 124.02 & 14.24 & 25.48 & 6.61 \\
\hline $50 \% \mathrm{f} / 50 \% \mathrm{c}$ & 12.76 & 98.91 & 13.47 & 22.70 & 6.10 \\
\hline $30 \% \mathrm{f} / 70 \% \mathrm{c}$ & 16.16 & 77.94 & 13.21 & 19.36 & 5.20 \\
\hline $100 \% \mathrm{cotton}$ & 19.77 & 54.41 & 12.60 & 14.42 & 4.22 \\
\hline LSD at 5\% & $\mathbf{0 . 7 7}$ & $\mathbf{2 . 4 8}$ & $\mathbf{1 . 0 9}$ & $\mathbf{1 . 1 9}$ & $\mathbf{0 . 3 7}$ \\
\hline
\end{tabular}

Table 5. Effect of yarn count on knitted fabrics quality properties

\begin{tabular}{|c|c|c|c|c|c|}
\hline \multirow{2}{*}{ Yarn count } & \multicolumn{5}{|c|}{ Knitted Fabrics properties } \\
\cline { 2 - 6 } & $\begin{array}{c}\text { Bursting strength } \\
\mathrm{kg} / \mathrm{cm} 2\end{array}$ & $\begin{array}{c}\text { Air permeability } \\
\mathrm{m} 3 / \mathrm{m} 2 / \mathrm{min} .\end{array}$ & $\mathrm{K} / \mathrm{S}$ & UPF & $\begin{array}{c}\text { Moisture } \\
\text { regain\% }\end{array}$ \\
\hline $20 \backslash 1 \mathrm{Ne}$ & 17.00 & 70.46 & 13.84 & 22.37 & 5.87 \\
\hline $30 \backslash 1 \mathrm{Ne}$ & 14.76 & 88.72 & 13.42 & 20.70 & 5.60 \\
\hline $40 \backslash 1 \mathrm{Ne}$ & 12.60 & 100.28 & 12.89 & 18.40 & 5.12 \\
\hline LSD at 5\% & $\mathbf{0 . 6 7}$ & $\mathbf{2 . 1 4}$ & NS & $\mathbf{1 . 0 3}$ & $\mathbf{0 . 3 2}$ \\
\hline
\end{tabular}

NS: insignificant 
Table 6. Effect of yarn count and blend ratio on knitting fabric quality properties

\begin{tabular}{|c|c|c|c|c|c|c|}
\hline \multirow[b]{2}{*}{$\begin{array}{l}\text { Yarn } \\
\text { count }\end{array}$} & \multirow[b]{2}{*}{$\begin{array}{c}\text { Fabric } \\
\text { construction }\end{array}$} & \multicolumn{5}{|c|}{ Knitting Fabric properties } \\
\hline & & $\begin{array}{l}\text { Bursting } \\
\text { strength } \\
\mathrm{kg} \mid \mathrm{cm} 2\end{array}$ & $\begin{array}{c}\text { Air permeability } \\
\mathrm{m} 3 / \mathrm{m} 2 / \mathrm{min}\end{array}$ & $\mathrm{K} / \mathrm{S}$ & UPF & $\begin{array}{l}\text { Moisture } \\
\text { regain\% }\end{array}$ \\
\hline \multirow{4}{*}{$20 \mathrm{~s}$} & $70 \% \mathrm{f} / 30 \% \mathrm{c}$ & 12.40 & 105.40 & 14.74 & 28.23 & 7.01 \\
\hline & $50 \% f / 50 \% c$ & 14.20 & 83.40 & 13.82 & 24.70 & 6.51 \\
\hline & $30 \% \mathrm{f} / 70 \% \mathrm{c}$ & 17.93 & 58.04 & 13.51 & 20.87 & 5.41 \\
\hline & $100 \%$ cotton & 23.47 & 34.99 & 13.28 & 15.69 & 4.55 \\
\hline \multirow{4}{*}{$30 \mathrm{~s}$} & $70 \% \mathrm{f} / 30 \% \mathrm{c}$ & 10.20 & 127.23 & 14.26 & 25.77 & 6.64 \\
\hline & $50 \% \mathrm{f} / 50 \% \mathrm{c}$ & 13.60 & 97.38 & 13.46 & 22.93 & 6.10 \\
\hline & $30 \% \mathrm{f} / 70 \% \mathrm{c}$ & 16.33 & 75.70 & 13.26 & 19.52 & 5.31 \\
\hline & $100 \%$ cotton & 18.90 & 54.57 & 12.70 & 14.61 & 4.37 \\
\hline \multirow{4}{*}{$40 \mathrm{~s}$} & $70 \% \mathrm{f} / 30 \% \mathrm{c}$ & 8.80 & 139.43 & 13.72 & 22.45 & 6.18 \\
\hline & $50 \% \mathrm{f} / 50 \% \mathrm{c}$ & 10.47 & 115.93 & 13.13 & 20.48 & 5.66 \\
\hline & $30 \% \mathrm{f} / 70 \% \mathrm{c}$ & 14.20 & 100.07 & 12.87 & 17.70 & 4.90 \\
\hline & $100 \%$ cotton & 16.93 & 73.67 & 11.83 & 12.97 & 3.73 \\
\hline \multicolumn{2}{|r|}{ at $5 \%$} & 1.34 & 4.29 & 1.89 & 2.07 & 0.637 \\
\hline
\end{tabular}

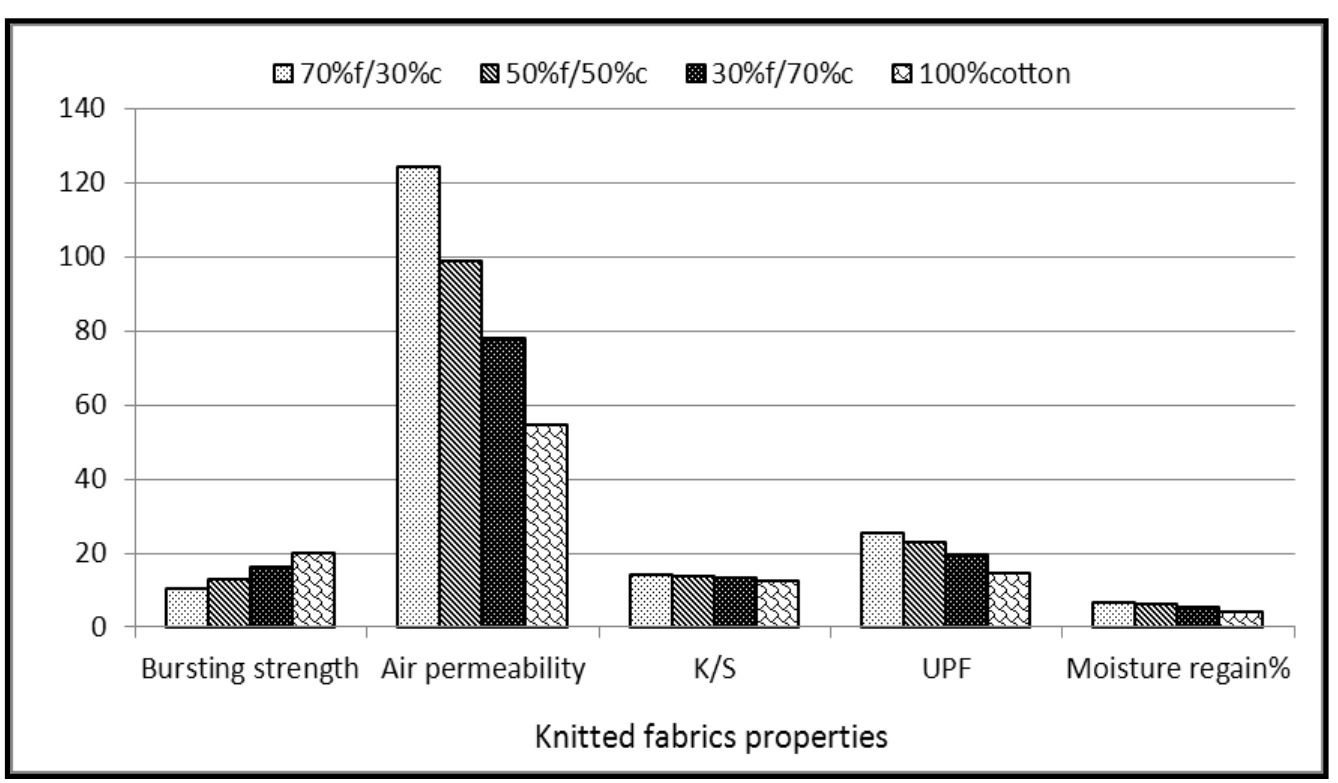

Figure 5. Effect of blend ratio on knitted fabrics quality properties 


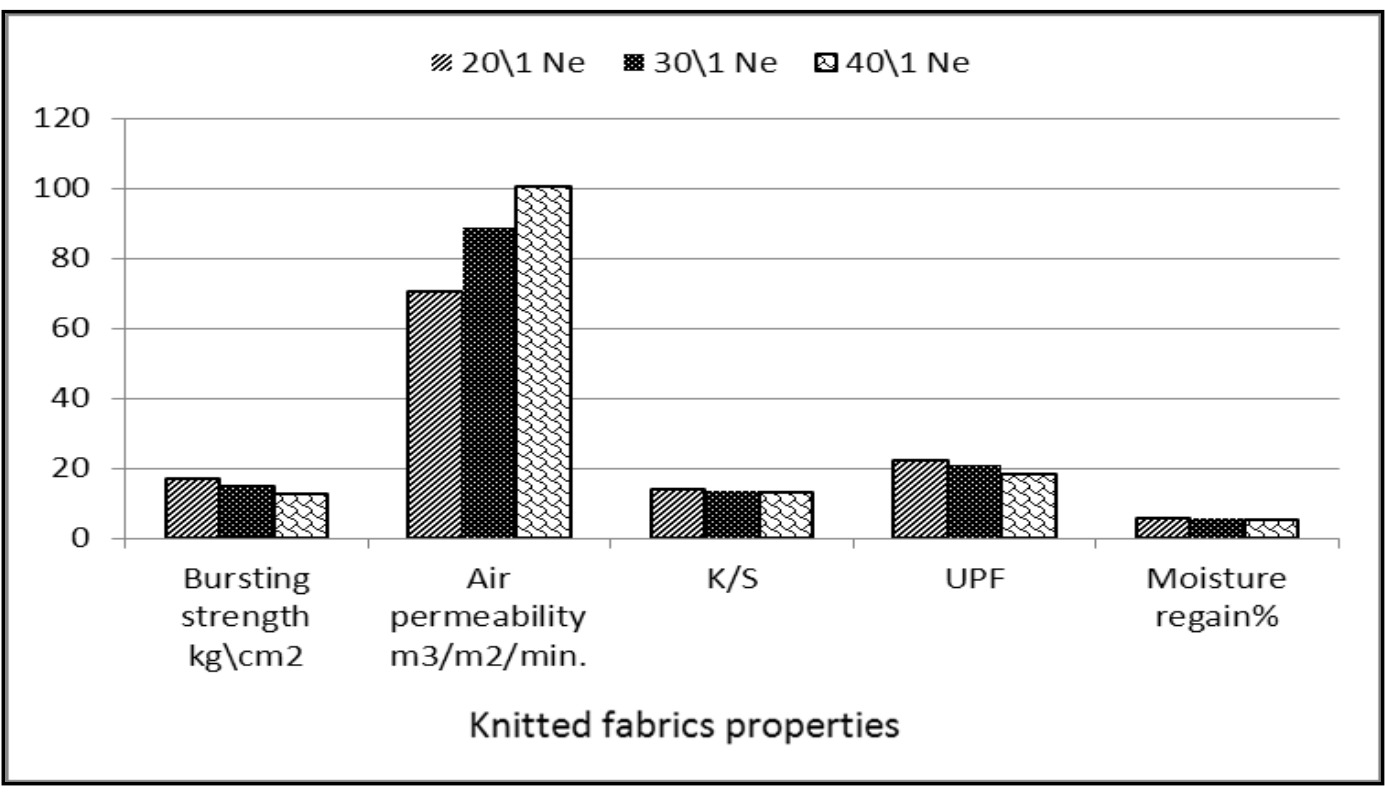

Figure 6. Effect of yarn count on knitted fabrics quality properties

\section{REFERENCES}

1. ASTM .1991. American Society for Testing and Materials. Standards of textile testing and materials, Philadelphia, Pa.

2. Behera. 2007.Comfort and Handle behavior of flax-blended fabrics. Autex Research Journal, Vol. 7, No 1, March 2007 @ AUTEX.

3. Bliss, R. M. and Jonn A. Foulk, 2005. Flax fiber offers cotton cool comfort. Agricultural Research magazine, Clemson, South Carolina, November 200512-13.

4. Capjack L., N, Kerr S,Davis R, Fedosejevs KL,Hatch NL. Markee 1994. Protection of humans from ultraviolet radiation through the use of textiles: A Review. Family and Consumer Sciences Research Journal. 23:198-218.

5. Cierpucha, W.Z. Czaplicki, J. Mańkowski, J. Kołodziej, S. Zaręba and J. Szporek.2006. Blended Rotor-Spun Yarns with a High Proportion of Flax. FIBRES \& TEXTILES in Eastern Europe January / December 2006, Vol. 14, No. 5 (59).

6. Draper, N. R. and R. Smith. 1966. Applied regression analysis. John Wiley and Sons, Inc., New York. 704 Pp.

7. Foulk, J. A., Wayne Y. Chao, Danny E. Akin, Roy B. Dodd and Patricia A. Layton. 2006. Analysis of Flax and Cotton Fiber Fabric Blends and Recycled Polyethylene Composites. Journal of Polymers and the Environment, Vol. 14, No. 1, January 2006. 
8. Kadolph, S. J. and A.L. Langford. 2002. Textiles. Upper Saddle River, New Jersey Prentice Hall. Copyright 2002 by Pearson Education, Inc.

9. Strumiłło, L.J., T. Jackowski, D. Cyniak and J. Czekalski. 2004. Neural Model of the Spinning Process for Predicting Selected Properties of Flax/Cotton Yarn Blends. FIBRES \& TEXTILES in Eastern Europe October / December 2004, Vol. 12, No. 4 (48).

10. Standard Guide for Labeling of UV-Protective Textiles," ASTM Designation: D 6603-00. ASTM International, 100 Barr Harbor Drive, PO Box C700, West Conshohocken, PA, 19428-2959 USA. 


\title{
إضافة صفات الراحة لأقمشة التريكو المنتجة من خلطات خيوط القطن والكتان والمغزولة على نظام الغزل الحلقى
}

أجريت هذه الدر اسة لتقدير ومقارنة صفات الر احة للخيوط و أقشة التزيكو و المصنو عة من خلطات بنسب مختلفة من الكتان القطنى (شعبرات الكتان التى تم قصها لطول 28 مم لتناسب خلطها

مع شعيرات القطن) وصنف القطن جيزة 80 من طبقة أقطان طويل التيلة بأستخدام نظام الغزل

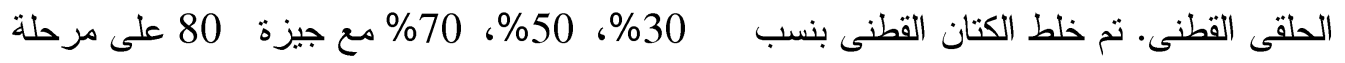

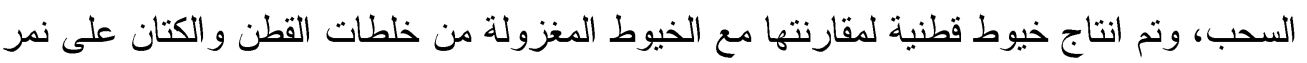
غزلية 20، 30 و 40 بالتزقيم الانجليزى على معامل برم 4.0. علاوة على ذلك تم تجهيز الخيوط

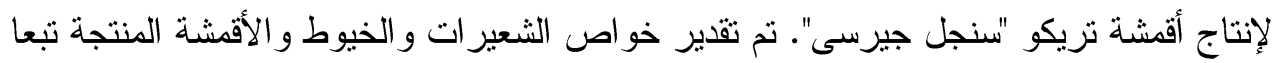
للمو اصفات القياسية الأمريكية. يمكن تلخيص النتائج المتحصل عليها كالتالى:

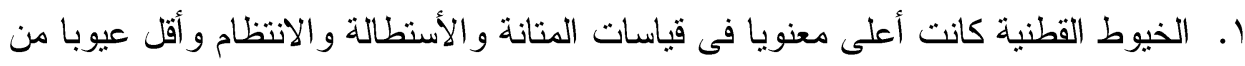
الخيوط المخلوطة من القطن و الكتان. r. بمقارنة نتائج قوة الانفجار لأقمشة التريكو وجد أن الأقمشة المصنوعة من من خلطات القطن و الكتان كانت بوجه عام أقل فى قوة الانفجار من الأقمشة القطنية.

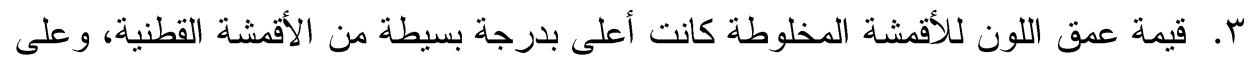
الرغم من هذا فان الاختلافات بين نسب خلطات الكتان مع القطن كانت غير معنوية.

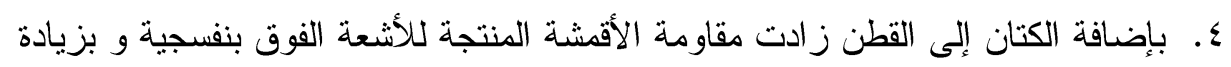

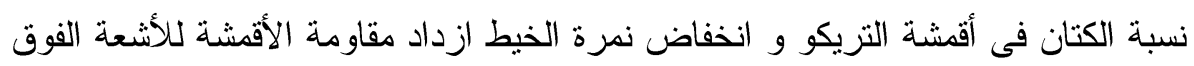
بنفسجية. ๑. أظهرت النتائج ان الأقشة المخلوطة من القطن والكتان تسمح بإمنصاص أعلى للرطوبة بالمقارنة بالأقشة القطنية وهذا راجع إلى زيادة قطر شعير الاتية الكتان.

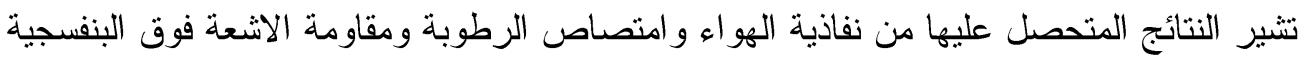
(خو اص الراحة) إلى أن أقمشة التزيكو المصنوعة من خلطات القطن و الكتان القطنى أكثر ملائمة لأقششة التريكو الصيفية بسبب زيادة نفاذية الهو اء وبالت الى سرعة الجنى الجفاف وكذلك زيادة مقاومتها 